ORIGINAL ARTICLE

AFRICAN JOURNAL OF CLINICAL AND EXPERIMENTAL MICROBIOLOGY. MAY 2014 ISBN 1595-689X VOL15 No.2

AJCEM/1411

COPYRIGHT 2014 http://dx.doi.org/10.4314/ajcem.v15i2.3

AFR. J. CLN. EXPER. MICROBIOL. 15(2):69-75

\title{
PREVALENCE OF ANTIBIOTIC-RESISTANT STRAINS OF ESCHERICHIA CO LI IN DRINKING WATER SAMPLES FROM MOWE METROPOLIS, OGUN STATE, NIGERIA
}

\author{
1Adenodi, S.A., 1Oyejide, N.E., 1Fayemi, S.O., 1,2Ayoade, F \\ 1. Department of Biological Sciences, College of Natural Sciences, Redeemer's University P.O. Box 812, Redemption Camp Post \\ Office, KM 46, Lagos-Ibadan Expressway, Redemption Camp, Ogun State, Nigeria \\ 2. Correspondence to: Dr. Femi Ayoade \\ E-mail: ayoadef@run.edu.ng
}

\section{ABSTRACT}

A measured Escherichia coli level in drinking water is perhaps the most popular means of determining human health risks globally. Water samples from wells, boreholes and sachet water, the 3 predominant sources of drinking water in the study area were evaluated for the presence of bacteria, particularly E coli. Bacteria isolation was done using standard microbiological procedures while identification of isolates was done using cultural, morphological and biochemical characteristics. Enumeration of standard plate count was done by spread plate method on serially diluted water samples. The prevalence of $E$ coli in the water samples and the activities of cefoxitin, fusidic acid, meticillin, penicillin and vancomycin against the $E$ coli isolates and the susceptibility testing data were obtained using Kirby Bauer method. A total of six bacteria species Escherichia coli, Pseudomonas aeruginosa, Bacillus cereus, Klebsiella pneumonia, Staphylococcus aureus, Enterobacter aerogenes were isolated from water samples obtained from borehole, well and sachet water samples in the study area. The mean bacteria counts ranged between $3.74 \times 104$ to $1.65 \times 102 \mathrm{CFU} / \mathrm{ml}$ for well and borehole water and 0.81 to $5.1 \times 102 \mathrm{CFU} / \mathrm{ml}$ for sachet water samples. Out of the $6 \mathrm{E}$ coli strains representing $27.2 \%$ of the isolated bacteria species; two, representing $33.3 \%$ of the strains showed moderate to high resistance against meticillin. These findings are expected to motivate public health stakeholders in the study location to attempt reducing the growing resistance of pathogenic bacteria in the environment, and their ecotoxic effects.

Key words: antibiotic resistance, meticillin, water quality, E. coli

\section{PREVALENCE DES SOUCHES RESISTANTES AUX ANTIBIOTIQUES D'ESCHERICHIA CO LI DANS LES ECHANTILLONS D'EAU POTABLE DANS LA MUNICIPALITE DE MOWE, L'ETAT D'OGUN, NIGERIA}

\author{
1Adenodi, SA, 1Oyejide, NE, 1Fayemi, SO, 1,2Ayoade, F
}

1Département des Sciences Biologiques , Université des sciences naturelles de l'Université PO Rédempteur Encadré 812 , rachat Camp bureau de poste , KM 46 , Lagos - Ibadan , Rachat Camp , Etat d'Ogun , Nigeria .

Adresse Mail d'auteur correspondant : Dr Femi Ayoade E -mail : ayoadef@run.edu.ng

RÉSUMÉ

Un niveau d'Escherichia coli mesurées dans l'eau potable est peut-être le moyen le plus populaire de la détermination des risques pour la santé humaine à l'échelle mondiale. Des échantillons d'eau de puits, de forages et de l'eau de sachet, les trois principales sources d'eau potable dans la zone d'étude ont été évalués pour la présence de bactéries, en particulier E. coli. L'isolement de bactéries a été effectué en utilisant des procédures microbiologiques standard tandis que l'identification des isolats a été effectuée à l'aide des caractéristiques culturelles, morphologiques et biochimiques. Énumération de nombre de plaque standard a été effectuée par la méthode de la plaque de propagation sur des échantillons d'eau dilués en série. La prévalence de $E$. coli dans les échantillons d'eau et les activités de la céfoxitine, l'acide fusidique, la méticilline, la pénicilline et de la vancomycine contre les isolats de $\mathrm{E}$. coli et les données de tests de sensibilité ont été obtenus en utilisant la méthode de Kirby Bauer. Un total de six espèces de bactéries:Escherichia coli, Pseudomonas aeruginosa, Bacillus cereus, Klebsiella pneumoniae, Staphylococcus aureus, Enterobacter aerogenes ont été isolés à partir d'échantillons d'eau provenant de puits, de forage et des échantillons d'eau de sachet dans la zone d'étude. Les bactéries, les valeurs moyennes se situaient entre 3,74 x 104 à $1,65 \times 102 \mathrm{UFC} / \mathrm{ml}$ pour le bien et l'eau de forage et de 0,81 à 5,1 x $102 \mathrm{UFC} / \mathrm{ml}$ pour les échantillons d'eau de sachet. Sur les 6 souches d'E.coli représentant $27,2 \%$ des espèces de bactéries isolées; deux $(33,3 \%)$ des souches ont montré une résistance modéré à haute à la pénicilline. Ces résultats devraient inciter les intervenants en santé publique dans le lieu de l'étude de tenter de réduire la résistance croissante des bactéries pathogènes dans l'environnement et leurs effets écotoxiques.

M ots clés: Résistance aux antibiotiques, pénicilline, qualité l'eau, E. coli. 


\section{INTRODUCTION}

About 2.5 billion people, roughly $40 \%$ of the world population lack access to safe drinking water (1). This teeming population of people are at risk of contacting water borne diseases, the most susceptible being children, the elderly, pregnant women and immunocompromised individuals. This makes waterborne illnesses one of the five leading causes of death among children under age five (2). $40 \%$ of deaths in developing nations occur due to infections from water related diseases and an estimated 500 million cases of diarrhoea, occurs every year in children below 5 years in parts of Asia, Africa and Latin America $(3,4)$. In Nigeria, drinking water pollution is further exacerbated due to the alarming rate of urbanization as major cities reportedly grow at rates between 10$15 \%$ per annum (5) and thus, human activities including soil fertility remediation, indiscriminate refuse and waste disposal, and the use of septic tanks, soak-away pits and pit latrines are on the increase. Groundwater pollution has been attributed to the process of industrialization and urbanization that has progressively developed over time without any regard for environmental consequences which eventually results in the deterioration of physical, chemical and biological properties of water $(6,7)$.

Microbial faecal contamination indicators of drinking water are Escherichia coli, Clostridium spp., Streptococci spp (8) and other bacteria that could be of human or non-human origin. Escherichia coli, particularly those possessing virulence markers as; haemolysin, verocytotoxin and belonging to the enteropathogenic serotypes have been responsible for gastroenteritis in humans (9). Drinking water safety guidelines and water quality regulations throughout the world rely on measured $E$. coli levels to indicate human health risks (10).

Antimicrobial resistance in Enterobacteriaceae poses a critical public health threat, especially in the developing countries $(4,11)$. Much of the problem has been shown to be due to the presence of transferable plasmids encoding multidrug resistance and their dissemination among different enterobacterial species (12). Escherichia coli O157 is an important food-borne and water-borne pathogen with a worldwide distribution (13). The first reported outbreak of E. coli O157 infection in the developing world occurred in 1992 in Southern Africa (14). Outbreaks have also occurred in Central African Republic in 1996 and Cameroon, in 1997 (15). Such outbreaks have been linked to contaminated bovine food products, contaminated drinking water and flood irrigation with water contaminated by animal feces or surface runoff and cattle feces have been implicated as the major source of contamination (14).

The emergence of antimicrobial resistance is usually preceded by antimicrobial misuse; however, surveillance of the spread of antimicrobial-resistant pathogens is expected to play a very important role in reducing the rate of emergence and spread of antimicrobial-resistant pathogens since such earlywarning signals make timely intervention possible. The present work examines the prevalence of antimicrobial-resistant strains of E. coli in the study area. Such monitoring can aid the infection-control community in reducing the emergence and spread of antimicrobial-resistant pathogens. Moreover, more work is being carried out to further characterize and to elucidate the mode of development of resistance in these isolated strains of $E$. coli.

\section{MATERIALS AND METHODS}

Water samples were obtained from 3 urban locations of Obafemi Owode Local Government, Ogun State namely, Mowe (N 06 48. 220' E 003 26. 167'),

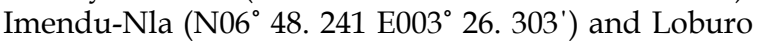

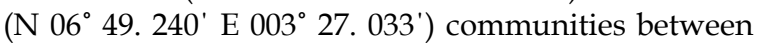
January and March, 2010. Bore-hole water collected at three different locations was designated B1, B2, and B3. Well water also collected at three different locations was designated W1, W2, and W3. The sachet water samples were purchased based on popularity at three different locations and were designated as S1, S2, S3, S4 and S5. Samples were labelled accordingly and taken to the laboratory for analyses within few hours after sampling. Physical characteristics such as specific odour and appearance and presence of extraneous materials and floating particles in the water samples were noted. Moreover, features external to the water itself such as the label and presence of certification number and other product information of the sachet water samples were also noted.

Total heterotrophic bacteria count of the drinking water samples was determined using pour plate method. The plates were inoculated aerobically at $37^{\circ} \mathrm{C}$ for 24 hours. The total coliform bacteria were determined using the multiple tube fermentation tests and the calculated coliform density computed by the Most Probable Number (MPN) procedures (16). All measurements of parameters were made in triplicates. Results obtained were statistically analyzed using Analyse-it@ v. 2.20, statistical software for Microsoft Excel. Variations were considered significant at $\mathrm{p} \leq 0.05$.

5 Antibiotic disks were obtained from Oxoid (Oxoid Ltd., Cambridge, UK): fusidic acid $(10 \mu \mathrm{g})$, penicillin (10 units), cefoxitin $(30 \mu \mathrm{g})$, meticillin $(10 \mu \mathrm{g})$ and 


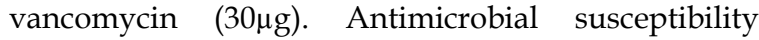
testing was performed using a disk diffusion method according to the Clinical and Laboratory Standards Institute (CLSI) guidelines (17). Quality control was performed using test strain E. coli ATCC 25922.

\section{RESULTS}

Physical examination of the untreated water samples from boreholes and wells examined in the present study revealed that none of the well water samples met the WHO standards for physical appearance. The well water samples were turbid and/ or with odour, unlike the samples from the borehole that were colourless, odourless and with no particles as recommended by the WHO (Table 1). Moreover, a visual appraisal of the wells and boreholes reveals that these were located within less than an average of 30 meters from a septic tank or waste dump. On the other hand, apart from displaying the manufacturer's name, address and NAFDAC number, none of the treated sachet water brands showed other necessary information such as batch number, date of manufacture and best before date (Table 2).

TABLE 1: RESULTS OF PHYSICAL EXAMINATION OF WATER SAMPLES

\begin{tabular}{ll|ll}
\hline Water Source & Colour/ Turbidity & Odour & Particles \\
\hline B1 & Colourless & Odourless & None \\
\hline B2 & Colourless & Odourless & None \\
\hline W1 & Slightly turbid & Slight odour & Few particles \\
\hline W2 & Colourless & Odourless & Few particles \\
\hline W3 & Slightly turbid & Slight odour & Suspended solids \\
\hline S1 & Colourless & Odourless & None \\
\hline S3 & Colourless & Odourless & None \\
\hline S4 & Colourless & Odourless & None \\
\hline
\end{tabular}

Key: B1 = borehole water samples from Imedu Nla; B2 = borehole water samples from Mowe; W1 = well water samples from Imedu Nla; W2 = Well water samples from Mowe; W3 = well water samples from Loburo; S1 = sachet water brand no. 1; S2 = sachet water brand no. 2; S3 = sachet water brand no. 3; S4 = sachet water brand no. 4

TABLE 2: RESULTS OF PHYSICAL EXAMINATION FOR LABELLING COMPLIANCE OF SACHET WATER SAMPLES

\begin{tabular}{|c|c|c|c|c|c|c|}
\hline Samples & $\begin{array}{l}\text { NAFDAC } \\
\text { number }\end{array}$ & $\begin{array}{l}\text { Best before } \\
\text { date }\end{array}$ & Manufacturing date & $\begin{array}{l}\text { Nutritional } \\
\text { information }\end{array}$ & $\begin{array}{l}\text { Batch } \\
\text { number }\end{array}$ & $\begin{array}{l}\text { Producer's } \\
\text { name \& } \\
\text { address }\end{array}$ \\
\hline S1 & + & - & - & - & - & + \\
\hline S2 & + & - & - & - & - & + \\
\hline S3 & + & - & - & - & - & + \\
\hline S4 & + & - & - & - & - & + \\
\hline S5 & + & - & - & - & - & + \\
\hline
\end{tabular}

Key: S1 = sachet water brand no.1; S2 = sachet water brand no. 2; S3 = sachet water brand no. 3; S4 = sachet water brand no. 4; S4 = sachet water brand no. 4; +: Displayed on sample label; - : Not displayed on sample label

Out of the 22 distinct bacteria isolates obtained from the water samples, the frequency of occurrence of $E$. coli was the highest (Table 3). $6 \mathrm{E}$ coli isolates representing $27.27 \%$ of the total was recovered from the water samples from all sources except the treated sachet water samples S1, S2, S3 and S4. E coli was isolated from water samples from all the untreated water sources namely location B1, B2, W1, W2, W3 including a treated water source, sachet water S5. This was followed by a frequency of 5 out of 22 isolates representing $22.73 \%$ each for Staphylococcus aureus and Enterobacter aerogenes (Table 3). Other bacteria species isolated from the water samples include Pseudomonas aeruginosa, Bacillus cereus and Klebsiella pneumonia each with a frequency of occurrence of 2 out of the total of 22 isolates representing $9.09 \%$ (Table 3 ). The widest variety of bacterial organisms was isolated from well water W1, which also had some odour and was slightly turbid.

Water samples from location B1 displayed the highest bacterial load with a standard plate count of $3.74 \times 102 \mathrm{cfu} / \mathrm{ml}$, water samples from this location was also found to contain coliform bacteria (Table 4). This is significantly higher than the bacterial load recorded for treated or untreated water samples from other locations (Table 4). Moreover, none of the treated sachet water samples contained coliforms, although a standard plate count revealed no significant difference in colony counts between the treated and untreated water sources with the exception of water samples from location B1 which displayed the highest standard plate count (Table 4). 
TABLE 4: TOTAL BACTERIA COUNT IS EXPRESSED IN COLONY FORMING UNITS (CFU) WHILE THE COLIFORM COUNT IS EXPRESSED IN MOST PROBABLE NUMBER (MPN) AS DESCRIBED IN CHEESEBROUGH (2000). VALUE WITH ASTERISK IS SIGNIFICANT AT P $\geq 0.05, \mathrm{X} 2=2.618, \mathrm{DF}=18$.

\begin{tabular}{ccc}
\hline & \multicolumn{2}{c}{ BACTERIAL LOAD (CFU/MPN) } \\
\cline { 2 - 3 } SAMPLES & $\begin{array}{c}\text { Standard plate count } \\
(\mathrm{cfu} / \mathrm{ml})\end{array}$ & $\begin{array}{c}\text { Total coliform count } \\
(\text { MPN })\end{array}$ \\
\hline LOCATION B1 & $3.74 \times 102^{*}$ & 180 \\
\hline LOCATION B2 & $0.98 \times 102$ & 160 \\
\hline LOCATION W1 & $1.51 \times 102$ & 160 \\
\hline LOCATION W2 & $0.78 \times 102$ & 160 \\
\hline LOCATION W3 & $1.65 \times 102$ & 160 \\
\hline SACHET 1 & Nil \\
\hline SACHET 2 & $0.81 \times 102$ & Nil \\
\hline SACHET 3 & $0.59 \times 102$ & Nil \\
\hline SACHET 4 & $0.51 \times 102$ & Nil \\
\hline SACHET 5 & $0.85 \times 102$ & Nil
\end{tabular}

TABLE 5A: ANTIBIOTIC SUSCEPTIBILITY PATTERN (\%) OF GRAM NEGATIVE BACTERIA ISOLATES

\begin{tabular}{|c|c|c|c|c|c|c|}
\hline $\begin{array}{l}\text { No. of } \\
\text { Isolates } \\
\text { tested }\end{array}$ & Organism isolated & $\begin{array}{l}\text { Fusidic } \\
\text { Acid }\end{array}$ & Penicillin & Cefoxitin & Meticilin & Vancomycin \\
\hline 6 & Escherichia coli & $\begin{array}{l}S \\
0.0\end{array}$ & $\begin{array}{l}\mathrm{R} \\
\mathbf{1 0 0}\end{array}$ & $\begin{array}{l}S \\
0.0\end{array}$ & $\begin{array}{l}\mathbf{R} \\
33.3\end{array}$ & $\begin{array}{l}R \\
100\end{array}$ \\
\hline 2 & $\begin{array}{l}\text { Pseudomonas } \\
\text { aeruginosa }\end{array}$ & $\begin{array}{l}S \\
0.0\end{array}$ & $\begin{array}{l}\mathrm{R} \\
\mathbf{1 0 0}\end{array}$ & $\begin{array}{l}S \\
0.0\end{array}$ & $\begin{array}{l}S \\
0.0\end{array}$ & $\begin{array}{l}\mathrm{R} \\
\mathbf{1 0 0}\end{array}$ \\
\hline 2 & $\begin{array}{l}\text { Klebsiella } \\
\text { pnuemoniae }\end{array}$ & $\begin{array}{l}S \\
0.0\end{array}$ & $\begin{array}{l}\mathrm{R} \\
100\end{array}$ & $\begin{array}{l}S \\
0.0\end{array}$ & $\begin{array}{l}S \\
0.0\end{array}$ & $\begin{array}{l}\mathrm{R} \\
100\end{array}$ \\
\hline 5 & $\begin{array}{l}\text { Enterobacter } \\
\text { aerogenes }\end{array}$ & $\begin{array}{l}\mathrm{R} \\
\mathbf{1 0 0}\end{array}$ & $\begin{array}{l}\mathrm{R} \\
\mathbf{1 0 0}\end{array}$ & $\begin{array}{l}\mathrm{R} \\
\mathbf{1 0 0}\end{array}$ & $\begin{array}{l}S \\
0.0\end{array}$ & $\begin{array}{l}\mathrm{R} \\
\mathbf{1 0 0}\end{array}$ \\
\hline Control & $\begin{array}{c}\text { E. coli } \\
\text { (ATC 25922) }\end{array}$ & $\begin{array}{l}S \\
0.0\end{array}$ & $\begin{array}{l}S \\
0.0\end{array}$ & $\begin{array}{l}S \\
0.0\end{array}$ & $\begin{array}{l}S \\
0.0\end{array}$ & $\begin{array}{l}S \\
0.0\end{array}$ \\
\hline
\end{tabular}

Key: S=Sensitive/susceptible; R= Resistant 
TABLE 5B: ANTIBIOTIC SUSCEPTIBILITY PATTERN (\%) OF GRAM POSITIVE BACTERIA ISOLATES

\begin{tabular}{|c|c|c|c|c|c|c|}
\hline $\begin{array}{l}\text { No. of } \\
\text { Isolates } \\
\text { tested }\end{array}$ & Organism isolated & $\begin{array}{l}\text { Fusidic } \\
\text { Acid }\end{array}$ & Penicillin & Cefoxitin & Meticilin & Vancomycin \\
\hline 2 & Bacillus cereus & $\begin{array}{l}S \\
0.0\end{array}$ & $\begin{array}{l}S \\
0.0\end{array}$ & $\begin{array}{l}S \\
0.0\end{array}$ & $\begin{array}{l}R \\
100\end{array}$ & $\begin{array}{l}R \\
100\end{array}$ \\
\hline 5 & Staphylococcus aureus & $\begin{array}{l}S \\
0.0\end{array}$ & $\begin{array}{l}R \\
100\end{array}$ & $\begin{array}{l}S \\
0.0\end{array}$ & $\begin{array}{l}S \\
0.0\end{array}$ & $\begin{array}{l}S \\
0.0\end{array}$ \\
\hline Control & $\begin{array}{c}\text { E. coli } \\
\text { (ATC 25922) }\end{array}$ & $\begin{array}{l}S \\
0.0\end{array}$ & $\begin{array}{l}S \\
0.0\end{array}$ & $\begin{array}{l}S \\
0.0\end{array}$ & $\begin{array}{l}S \\
0.0\end{array}$ & $\begin{array}{l}S \\
0.0\end{array}$ \\
\hline
\end{tabular}

Key: $S=$ Sensitive/susceptible $R=$ Resistant

Antibiotics are used extensively to prevent or treat microbial infections in human and veterinary medicine. Apart from their use in aquaculture, they are also employed to promote more rapid growth of livestock. Most of the compounds used in medicine are only partially metabolized by patients and are then discharged into the sewage system or end up in the environment, mainly in the groundwater compartment (23). There is increasing concern about the growing resistance of pathogenic bacteria in the environment, and their ecotoxic effects. Increasingly, antibiotic resistance is seen as an ecological problem. This includes both the ecology of resistance genes and that of the resistant bacteria themselves. Little is known about the effects of sub-inhibitory concentrations of antibiotics and disinfectants on environmental bacteria, especially with respect to resistance. The results of the present study showing that $33.3 \%$ of the E. coli isolates from well and borehole samples were meticilin resistant. The present results is a warning signal to all stakeholders in community health in the study location to direct action at protecting drinking water from faecal contamination and limiting persistence of antimicrobials in groundwater. Future studies will focus on determining the genetic source(s) of the observed antimicrobial resistance. 


\section{REFERENCES}

1. Salaam-Blyther, T. (2012). Global Access to Clean Drinking Water and Sanitation: U.S. and International Programs. Congressional Research Service 2012 Report. Accessed from http://www.fas.org/sgp/crs/misc/R42717.pdf on 9th January, 2014.

2. Hunter P. R. (2003). Drinking Water and Infectious Disease: Establishing the Links. Eds. Hunter P.R, Waite M., Ronchi E. CRC Press LLC, Florida, USA. ISBN 0-8493-1259-0

3. Adejuwon J. O. and Mbuk, C. J. (2011). Biological and physiochemical properties of shallow wells in Ikorodu town, Lagos Nigeria J ournal of G eology and M ining Research 3(6), 161-168.

4. WHO, World Health Organization (2008). WHO guidelines for drinking water quality, incorporating the first and second addenda volume 1. Recommendations. World Health Organization, Geneva p. 668. Accessed from www.who.int/water_sanitation_health/dwq/fulltext.p df on 9th January, 2014.

5. Yusuf, K. A. (2007). Evaluation of groundwater quality characterisitics in Lagos-City. Journal of A pplied Sciences 7(13), 1780-1784.

6. Isikwue, M. O., Iorver, D. and Onoja, S. B. (2011). Effect of depth on microbial pollution of shallow wells in Makurdi Metropoilis, Benue State, Nigeria. British Journal of Environment and Climate Change 1(3), 66-73.

7. Longe, E. O. and Balogun, M. R. (2010). Groundwater quality assessment near a Municipal Landfill, Lagos, Nigeria. Research Journal of Applied Sciences Engeering and Technology 2(1), 39-44.

8. Scott, T. M., Rose, J. B., Jenkins, T. M., Farrah, S. R. and Lukasik, J. (2002). Microbial source tracking: Current methodology and future directions. Applied Environmental M icrobiology 68, 5796-5803.

9. Karch H, Tarr PI, Bielaszewska M. (2005). Entero haemorrhagic Escherichia coli in human medicine. Int. J. M ed. M icrobiol. 295:405-418.

10. Brown J. M., Proum S. and Sobsey M. D. (2008). Escherichia coli in household drinking water and diarrheal disease risk: evidence from Cambodia. W ater Science and Technology 58(4): 757-763

11. Karlowsky, J.A.; Jones, M.E.; Thornsberry, C.; Friedland, I.R. (2003). Trends in antimicrobial susceptibilities among Enterobacteriacae isolated from hospitalized patients in the United States from 1998-2001. A ntimicrob. A gents Chemother. 47, 1672-1680.

12. Blake, D.P.; Humphry, R.W.; Scott, K.P.; Hillman, K.; Fenlon, D.R.; Low, J.C. (2003) Influence of tetracycline exposure on tetracycline resistance and the carriage of tetracycline resistance genes within commensal Escherichia coli populations. J. A ppl. M icrobiol., 94, 1087-1097

13. Matthews, L, Reeve, R., Gally, D.L., Low, J.C., Woolhouse, M.E.J., McAteer, S.P., Chase-

Topping, M.E., Haydon, D.T., Allison, L.J., Hanson, M.F., Gunn, G.J., Reid, S.W.J (2013) Predicting the public health benefit of vaccinating cattle against Escherichia coli 0157 Proc. O f N atl A cad. Of Sci 110 (40): 16265-16270

14. Effler $\mathrm{P}$, Isaacson $\mathrm{M}$, Arntzen $\mathrm{L}$, Heenan $\mathrm{R}$, Canter P, Barrett T, Lee L, Mamba C, vine W, Zaidi A, Griffin PM (2001). Factors contributing to the emergence of Escherichia coli O157: H7 in Africa. Emerging Infectious D iseases 7: 812-819.

15. Cunin P, Tedjouka E, Germani Y, Ncharre C, Bercoin R, Morvan J. (1999). An epidemic of blood diarrhoea: Escherichia coli O157 emerging in Cameroon? Emerging Infectious Diseases 5: 285290.

16. APHA, American Public Health Association ( 2001). Compendium of methods for the microbiological examination of foods. 4th edn., Eds. Downes, F.P. and K. Ito. Sheridan Books Inc., Washington D.C., USA. ISBN: 0-87553-175x

17. CLSI, Clinical Laboratory Standards Institute (2007) Performance Standards for Antimicrobial Testing: Seventeenth International supplement. M100-817 Vol. 27 No. 1 182pp. Accessed from http://www.microbiolab-bg.com/CLSI.pdf on 9th January, 2014.

18. Adetunji, V.O. and Odetokun, I. A. (2011) Groundwater contamination in Agbowo community, Ibadan Nigeria: Impact of septic tanks distances to wells. Malaysian Journal of Microbiology, 7(3) 2011, 159-166 ISSN (print): 1823-8262, ISSN (online): 2231-7538

19. Chiroma, T. M., Ugheoke, B. I. and Patrick, D. O. (2007). Environmental impact on the quality of water from hand-dug wells in Yola Environs. A cademic Direct 10, 67-76.

20. Fong, T. T., Mansfield, L. S., Wilson, D. L., Schwab, D. J., Molloy, S. L. and Rose, J. B. (2007). Massive microbiological groundwater contamination associated with a waterborne outbreak in Lake Erie, South Bass Island, Ohio. Environmental H ealth Perspectives $115,856-863$.

21. Gerba C. and James, E. (2005). Sources of pathogenic microorganisms and their fate during land application of wastes. Journal of Environmental Q uality 34, 42-48.

22. USEPA (United States Environmental Protection Agency) (2009). National Primary Drinking Water Regulations. EPA 816F-09-004. Washington, D.C.

23. Kummerer, K. (2004) Resistance in the environment. Journal of Antimicrobial Chemotherapy 54:311-320 